\title{
Tax Incentives Issue for Innovations in Sustainable Energy within the BRICS strategic partnership framework
}

\author{
Ekaterina Kudryashova ${ }^{1}$, and Anna Shashkova ${ }^{2}$ \\ ${ }^{1}$ The Institute of legislation and comparative law under the Government of Russian Federation (Moscow, Russia) \\ ${ }^{2}$ Moscow State Institute of International Relations (MGIMO-University) (Moscow, Russia)
}

\begin{abstract}
The energy sector is one of the key topics in agenda of the BRICS strategic partnership. There are a few steps taken towards the development of sustainable energy innovations as well. However, this direction of strategic partnership is not supported by the other BRICS cooperation channels like the cooperation on tax matters. The tax incentives for the sustainable energy innovations could be part of the tax capacity building announced in the BRICS documents elaborated during the BRICS countries Revenue Authorities.
\end{abstract}

\section{Introduction}

The transformation to the sustainable energy systems becomes the key issue not only of the science and technology, but also for the international cooperation and unions. The more sustainable energy becomes the priority for the economy development the stronger tax and other financial incentives are expected in this field.

The world development trends nowadays are inconceivable without taking into consideration the BRICS (Brazil, Russia, India, China and South Africa) strategic partnership. The BRICS-countries represent the major economies in the world. In terms of population in 2016 these countries had around 43 percent of the world. The future development of BRICS in all arears including the sustainable energy will have a substantial impact on the world's trends in development.

During the recent twenty years quite a few publications related to the green fiscal reforms were presented to the academic audience including monographs and essay collections $[1,2,3]$. However, there is a substantial gap in studies of the economic incentives for the innovations in the energy sector within the BRICS framework. The research issue of this paper is the possible cooperation on tax incentives policies as a support for the BRICS sustainable energy agenda.

\section{Methods}

This research is based on several methods due to the sophisticated subject area. The system-structural method is employed for the study of the general trends in the energy sector development. BRICS represents a complicated modern phenomenon in the international relations therefore the integrated approach is needed for better understanding the relevant facts and their wider political and social context.
While scrutinizing the documents and facts related to the BRICS cooperation the general scientific methods of analysis and synthesis is successfully used. The spectrum of methods employed in this paper includes the dialectical metho.

\section{Results}

The cooperation in the energy sector including the sustainable energy issues play an important role in the BRICS strategic partnership. At the same time the taxation matters discussed within the BRICS are mostly limited to the tax administration like transfer pricing, automatic information exchange, tax base erosion etc. In this respect the processes in cooperation on tax matters do not reflect the developments of sustainable energy innovations. The proactive tax matters like coherent tax treatment of the investments to the energy innovations or tax incentives are not covered by the tax authorities cooperation agenda We suggest that the tax incentives for the sustainable energy innovations could be part of the tax capacity building announced in the BRICS documents.

\section{Discussion}

The macroeconomic strategic coordination without dominance of any actor becoming popular basis for international alliances and associations between the counties [4]. After nearly ten years of successful development the BRICS achieved a sound position in the international order and this position was prepared by long history of political cooperation and the process of the multipolarization of the world [5]. The membercountries political systems are in constant motion [6,7] and the BRICS framework has to keep pace with the 
political changes. "BRICS Strategic Partnership for Global Stability, Shared Security and Innovative Growth" is the current motto of BRICS.

The BRICS counties cooperation in the energy sector was quite active and mutually beneficial. The sustainable energy issues were also involved in the interactive processes within BRICS, but still the BRICS partnership is mostly concerned the energy security rather than the transformation to the renewable and green energy sources.

The cooperation and coordination in the energy sector first was mentioned in the Joint statement of the BRICS Countries leaders on June, 16, 2009 in Yekaterinburg. Since the Delhi Declaration, made on March, 29 of 2012 in New Delhi the cooperation and general development in the energy field was launched. According to the Ethekwini Declaration of 27, March 2013 the new areas of cooperation to be explored included the energy sector. Energy sector was mentioned in each and every declaration since the energy sector was included in the list of arears of BRICs cooperation.

On the Summit in South Africa in 2013 Russia proposed to develop a long-term strategy of economic cooperation which implied the cooperation in energy sector as well. BRICS Summit in Ufa on July 9, 2015 pushed the economic cooperation in all spheres by means of the BRICS Economic Partnership Strategy where the importance of promoting energy cooperation with sharing experiences in the areas related to energy production and consumption, energy planning was emphasized [8]. The experts insist on the need for the coordination and even unification of the national legislation relevant for the energy sector [9].

The sustainable energy and green economy are mentioned in the BRICs documents since 2011. In the Sanya Declaration of 14, April 2011 the leaders confirmed that they support the use of renewable energy resources and recognize the important role of renewable energy in the climate change action plan. Since than a few agreements were signed on the cooperation in green economy, certain steps were taken in the direction of the sustainable energy technologies exchange, a few projects were financed by the BRICs institutions of development.

The networking and contacts on the taxation matters developed parallel to other topics of the BRICS partnership. The BRICS coordination on tax matters started in the 2013 with a Communique of BRICS heads of Revenue Authorities Meeting of 18, January (New Delhi) [10]. On this meeting the initial areas of mutual interests were identified. These areas of mutual interest included the international taxation, transfer pricing, exchange of information, prevention of tax evasion and avoidance. Only the point on sharing of best practices and capacity building could be considered as the proactive part of the cooperation.

Next milestone in the coordination on tax matters was the Communique of BRICS Heads of Revenue Authorities Meeting, 19 November, 2015 Moscow [11]. The Communique of 2015 amplified the tax agenda with the tax base erosion issues, digital economy and crossborder e-trade. The general commitment to promoting closer cooperation on issues of common interest was reaffirmed. The Communique of BRICS Heads of Revenue Authorities Meeting of 6, December, 2016 (Mumbai) [12] replicated and reaffirmed the previous agenda. The Communique of BRICS Heads of Revenue Authorities Meeting, 21 January, 2018 (Johannesburg) [13] reaffirming again the previous declarations mentioned the tax capacity building as a critical point for the Fourth Industrial Revolution.

The analysis of the BRICS documents on the tax matters show that the coordination on tax matters goes somewhat parallel with the general trends of BRICS cooperation. There is a lack of intersecection with other main BRICS topics like the cooperation in the energy sector. Although the BRICS sustainable energy projects call for sound fiscal and tax solutions for their promotion. The tax agenda do not reflect these aspects of BRICS cooperation.

The modern academic researches show that there are interesting and efficient tax practices stimulating the innovative economic activity in each BRICS membercountry. The studies even show that there is much in common in tax policies encouraging investments in innovations and new technologies in BRICS counties including the advanced technologies in the energy sector. $[14,15]$. However, no substantial attention was paid on the meetings between the BRICS Revenue authorities to the exchange of the best tax practices and optimal tax treatment of the sustainable energy innovations leaving alone the elaboration of general approaches.

Once the tax issues and uncertainties are not identified and discussed within the BRICS cooperation on tax matters the efforts aimed to promote the sustainable energy sector may result in international tax exposure.

\section{Conclusion}

The general cooperation within BRICS strategic partnership on the sustainable energy should be complimented with the coordination on taxation matters and exchange of best tax policy features related to the sustainable energy innovations. Special attention should be paid to the tax incentives which could make the tax systems of BRICS countries more proactive and friendly for the innovations in energy sector. The coherent approaches can not directly influence the BRICS countries' tax policy, however, they could ensure favorable political context and a long-term consistent prospective.

\section{References}

[1] L. Keiser, S. Lee, K. Ueta, J.E. Miline, H. Ashiabor (eds.), Environmental Taxation and Green Fiscal Reform: theory and impact (Edward Elgar Publishing, 2014)

[2] P. Ekins, S. Speck (eds.), Environmental Tax Reform: A Policy for Green Growth (Oxford, Oxford University Press, 2011) 
[3] R. Cullen, J. Vander Wolk, Y. Xu (eds.), Green Taxation in East Asia (Cheltenham, Edward Elgar, 2011)

[4] S. Shokhin, E. Kudryashova (2019) Macroeconomic Coordination in the Eurasian Economic Union: Strategic Aspects, Russian Law Journal 7, 3, 38 (2019)

[5] F. Cooper, The BRICS: A Very Short Introduction (Oxford University Press, 2016)

[6] M. Verlaine, A. Shashkova, E. Kudryashova, The amendments of Russian Constitution 2020 and the international institutions decisions and resolutions: the EAEU prospective, Polis, Political Studies 5, 164-176 (2020)

[7] A. Shashkova, M. Verlaine, E. Kudryashova, On Modifications to the Constitution of the Russian Federation in 2020, Russian Law Journal 1, 8, 60-83 (2020)

[8] M.O. Ryazanova, Energy cooperation within the BRICS: Relevance of the issue, Bulletin of MGIMO 4, 94, 7-11 (2015)

[9] A.O. Inshakova, I.P. Marchukov, General Energy Policy and Ways of Development of Legal Regulation of Foreign Trade Turnover of Energy Resources of the BRICS Countries in Energy Sector: A Systematic Analysis of Economy, Foreign Trade and Legal Regulations, O. Inshakov, A. Inshakova, E. Popkova (eds), Lecture Notes in Networks and Systems 44, Springer, Cham (2019)

[10] Communique of BRICS heads of Revenue Meeting of 18 January 2013 [Electronic resource], New Delhi (2013) Available at: https://www.nalog.ru/html/sites/www.new.nalog. ru/docs/inttax/CommuniqueIndia_2013.pdf

[11] Communique of BRICS Heads of Revenue Meeting 19 November 2015 [Electronic resource], Moscow (2015) Available at: https://www.nalog.ru/html/sites/www.new.nalog. ru/docs/inttax/CommuniqueMoscow2015.pdf

[12] The Communique of BRICS Heads of Revenue Meeting of 6 December 2016 [Electronic resource], Mumbai (2016) Available at: https://www.nalog.ru/html/sites/www.new.nalog. ru/docs/inttax/CommuniqueMumbai2016_signed .pdf

[13] The Communique of BRICS Heads of Revenue Authorities Meeting, 21 January 2018 [Electronic resource], Johannesburg Available at: https://www.nalog.ru/html/sites/www.new.nalog. ru/docs/inttax/Communique_signed1819.pdf

[14] E. Makeeva, I. Mikhaleva, Taxation regulation of the BriCs' innovative Companies, BRICS Law Journal 6, 1, 41-62 (2019)

[15] S.A. Tronin, T.A. Rodemel, M.G. Uspaeva, A.V. Shashkova, M. Calesi, Formation of Innovative Strategies of Regional Economic
Development, Space and Culture, India, 65-75 (2019) 